\title{
Congenital Aortic Valve Insufficiency
}

National Cancer Institute

\section{Source}

National Cancer Institute. Congenital Aortic Valve Insufficiency. NCI Thesaurus. Code C103936.

Dysfunction of the aortic valve characterized by incomplete valve closure that is present at birth. 